\title{
The Miocene Keramidomys (Rodentia, Eomyidae) from the Sandelzhausen locality (Germany)
}

\author{
Pierre Mein
}

Received: 30 September 2006/Accepted: 14 May 2007/Published online: 24 February 2009

(C) Springer-Verlag 2009

\begin{abstract}
In this note the taxonomic position of the tiny eomyid genus Keramidomys (Hartenberger, 1967) from the Early/Middle Miocene boundary locality of Sandelzhausen in the Bavarian Upper Freshwater Molasse is reexamined. As the chronological dating of the Sandelzhausen fossil site has been modified in the past from formerly the Neogene mammal unit MN6 to now MN5 and thanks to new abundant material this rodent is compared with other European forms. It is shown that the Sandelzhausen eomyid must be called K. thaleri Hugueney \& Mein, 1968 on the basis of several morphological dental differences from K. carpathicus Schaub \& Zapfe, 1953. This rodent seems to be an immigrant from East Asia into Europe. Even if $K$. thaleri is known in many European localities, all correlated to MN5, it is always a rare element of European rodent faunas. Differentiation from $K$. carpathicus is not easy and requires a sufficiently large sample.
\end{abstract}

Keywords Rodents - Keramidomys - Miocene ·

MN5 - Sandelzhausen · Bavaria

Kurzfassung Diese Untersuchung widmet sich der Überprüfung der taxonomischen Stellung der sehr kleinwüchsigen Eomyiden-Gattung Keramidomys (Hartenberger, 1967) aus der bayerischen Oberen Süßwassermolasse der Lokalität Sandelzhausen. Die Alterseinstufung der Fauna von Sandelzhausen wurde in

P. Mein ( $\square)$

Département des Sciences de la Terre,

Université Claude Bernard I,

27-43 boulevard $\mathrm{du}$,

69621 Villeurbanne Cedex, France

e-mail: pierre.mein@univ-lyon1.fr der Vergangenheit mehrmals korrigiert und wird nun der Säugetier-Stufe MN5-im Grenzbereich von Unter-zu Mittelmiozän-zugeordnet. Die vorliegende Arbeit stellt ein neues, reichhaltiges Material von Keramidomys aus Sandelzhausen vor, das umfangreiche Vergleiche mit anderen europäischen Formen erlaubt. Der Eomyide aus Sandelzhausen kann auf der Basis zahlreicher morphologischer Unterschiede zu K. carpathicus Schaub \& Zapfe, 1953 als K. thaleri Hugueney \& Mein, 1968 bestimmt werden. Keramidomys scheint aus Ostasien nach Europa eingewandert zu sein und ist stets ein seltenes Faunenelement in den europäischen Nagetierfaunen, auch wenn es aus vielen europäischen Lokalitäten der Säugetier-Zone MN5 bekannt ist. Die Unterscheidung von $K$. thaleri und $K$. carpathicus ist nicht einfach und bedarf einer ausreichend großen Materialmenge.

Schlüsselwörter Nagetiere $\cdot$ Keramidomys $\cdot$ Miozän · MN5 - Sandelzhausen - Bayern

\section{Introduction}

The vertebrate fossil site Sandelzhausen is located in the Bavarian North Alpine Foreland Basin (Southern Germany), near the town of Mainburg, about $70 \mathrm{~km}$ north of Munich. The limnofluvial deposits of Sandelzhausen belong to the Upper Freshwater Molasse. Based on mammal biostratigraphy the Sandelzhausen fauna was referred to the European Mammal Neogene Unit MN5 by Heissig (1997). Based on recent bio-, litho- and magnetostratigraphic analyses the stratigraphic position of the locality Sandelzhausen is situated at or very close to the Early/ Middle Miocene boundary (Karpatian/Badenian boundary) (Moser et al. 2009, this volume). 
Fahlbusch (1975) was the first to study the specimens of this family from Sandelzhausen but at that time he had only 25 teeth at his disposal; since then 300 additional teeth have been collected so that it is possible now to have a better view of variation in the group.

The Eomyidae is an extinct family of myomorphous rodents which lived throughout the Holarctic region during most of the Cenozoic Era; they appeared in Europe during the Lower Oligocene and were very numerous and diversified. Often they were the dominant small mammals in the Upper Oligocene and the Lower Miocene.

Two major syntheses of this group have been published: Fahlbusch (1979) gave a complete schema and Engesser (1999) wrote about the European forms. According to these papers, the Eomyids declined during MN4 at the end of which the last genus Ligerimys Stehlin \& Schaub, 1951 vanished. At about the same time, two new genera appeared in Europe: Keramidomys (Hartenberger, 1967) and Eomyops (Engesser, 1979), the latter genus remaining very rare during MN5 and MN6. To date, only two localities have yielded the genus Keramidomys in association with the genus Ligerimys: from France Vieux Collonges and from Poland Belchatow B. From Gashunyindege (China) Qiu \& Wang (1999) mentioned Keramidomys and Leptodontomys Shotwell, 1956 (=Eomyops) at the beginning of MN4. Some years ago it was thought that Keramidomys was a local successor to Pseudotheridomys Schlosser, 1926; this hypothesis, which would imply a size reduction and a Lazarus effect, is no longer supported today. More probably it seems that both genera originated in East Asia. Sandelzhausen has yielded only one eomyid genus: Keramidomys. Although these two genera were never common they survived until the beginning of the Quaternary Epoch. Fahlbusch \& Bolliger (1996) gave a list of the European localities where Keramidomys and Leptodontomys are present; in this paper, Table 1 lists the known localities for Keramidomys during MN5 and MN6. Later different species may coexist but they remain rare and occur in only a few localities.

\section{Materials and methods}

The material presented here is housed at the Bayerische Staatssammlung für Paläontologie und Geologie Munich (BSPG) under the collection number BSPG 1959 II xxxxx; in the following, only the last part of the inventory number is given. The entire material is listed in Tables 2, 3, 4, 5 and 6. For the description, the dental terminology proposed by Engesser (1999) is used. Following abbreviations indicate the different tooth positions: upper deciduous molar (D), premolars (P), and molars (M) and lower deciduous molar (d), premolars (p) and molars (m).
Table 1 MN5 and MN6 localities with Keramidomys

MN5 localities with Keramidomys

Spain

Lumiar 7 (Daams, personal communication)

Vargas $7 \mathrm{~g}$ (Daams, personal communication)

France

Lo Fournas 2 (Aguilar et al. 1986)

Vieux Collonges (Hugueney and Mein 1968)

Switzerland

Chatzloch (Kälin 1997)

Chlaustobel (Bolliger 1992)

Güntisberg (Bolliger 1992)

Hombrechtikon-Hotwiel (Bolliger 1992)

Hombrechtikon-Sperstr. (Bolliger 1992)

Hombrechtikon-Tobel (Engesser 1990)

Hüllistein (Bolliger 1992)

Martin brünneli (Kälin 1997)

Stäfa-Burgistobel A (Bolliger 1992)

Stäfa-Schliffitobel B (Bolliger 1992)

Vermes 1 (Engesser 1990)

Vermes 2 (Kälin 1997)

Werthenstein-Grabenhüsli (Engesser 1990)

Bohemia

Franzenbad (Fejfar 1974)

Strakonice (Fejfar 1974)

Germany

Adelschlag (Fahlbusch 1975)

Edelbeuren-Maurerkopf (Sach 1999)

Eitensheim (Fahlbusch 1975)

Engelwies 1 (Ziegler 1995)

Gisseltshausen 1b (Heissig 1989)

Gundlkofen (Fahlbusch 1975)

Hambach C (Mörs et al. 2000)

Langenmoosen (Fahlbusch 1975)

Massendorf (Schötz 1979)

Niederreichbach (Schötz1979)

Oggenhof (Fahlbusch 1975)

Pöttmes (Fahlbusch 1975)

Puttenhausen (Fahlbusch and Wu 1981)

Rosshaupten (Fahlbusch 1975)

Sandelzhausen (Fahlbusch 1975)

Schönenberg (Fahlbusch 1975)

Undorf (Fahlbusch 1975)

Unterneul 1a (Heissig 1989)

Obergänserndorf (Daxner-Höck 1998)

Teiritzberg (Daxner-Höck 1998)

Poland

Belchatow (Kowalski and Rzebik-Kowalski 2002)

Turkish Republic

Candir (De Bruijn et al. 2003) 
Table 1 continued

\begin{tabular}{l}
\hline MN6 localities with Keramidomys \\
France \\
Sansan (Engesser 1979) \\
Switzerland \\
Chatzloch (Kälin 1997) \\
Chrüzbuel-Ruehalden (Bolliger 1992) \\
Gerstel (Bolliger 1992) \\
Schauenberg (Bolliger 1992) \\
Germany \\
Gallenbach 3a2b (Heissig 1989) \\
Unterzolling 1a (Heissig 1989) \\
Slovakia \\
Neudorf Spalte (Fejfar 1974; Daxner-Höck 1998) \\
Poland \\
Opole 2 (Kowalski 1967) \\
Turkish Republic \\
Pismanköy (Unay and de Bruijn 1984) \\
Central Mongolia \\
Ulaan Tolgoi (Höck et al. 1999) \\
\hline
\end{tabular}

\section{Research history of the taxon Keramidomys}

The genus Keramidomys was erected by Hartenberger (1967) for the Lower Vallesian species from Can Llobateres (Spain): Keramidomys pertesunatoi Hartenberger, (1967). Soon afterwards Hugueney \& Mein (1968) included in this genus a new species from the Lower Middle Miocene of Vieux Collonges (France): Keramidomys thaleri, characterised by a long syncline I in the M1 and M2.

The original diagnosis for $K$. thaleri is as follows (translated from French from Hugueney \& Mein, 1968):

"Very small eomyid with a relatively high crown and a plane occlusal surface. $\mathrm{m} 1$ and $\mathrm{m} 2$ have four roots; P4 and $\mathrm{m} 3$ are smaller and less complicated than the other teeth that differentiate them from Pseudotheridomys teeth; this species differs from K. pertesunatoi Hartenberger (1967) and from Keramidomys carpathicus Schaub \& Zapfe (1953) because of the unreduced first buccal syncline in upper molars and in the always well-preserved mesoloph and mesolophid".

It was Hugueney \& Mein (1968) who referred Pseudotheridomys carpathicus Schaub \& Zapfe (1953), described from Neudorf Spalte (Slovak Republic), to Keramidomys. This last species was reexamined and figured in Fejfar (1974), who described its great morphological variability and showed some teeth with a long syncline. Fahlbusch (1975) studying new material from the Upper Freshwater Molasse of Bavaria concluded that the sample of $K$. thaleri is too small to provide a good idea of the variability and does not present really discriminant characteristics. So, he preserved only the name $K$. carpathicus for the small
Table 2 Measurements (mm) of D4, P4, M3 of Keramidomys thaleri from Sandelzhausen, including mean and standard deviation

\begin{tabular}{|c|c|c|c|c|c|}
\hline Inventory no. & Length & Width & Inventory no. & Length & Width \\
\hline \multicolumn{3}{|l|}{ D4 } & \multicolumn{3}{|l|}{$\mathrm{P} 4$} \\
\hline 10037 sin. & 0.76 & 0.69 & 5387 sin. & 0.67 & 0.75 \\
\hline 10038 sin. & 0.74 & 0.77 & $10015 \sin$. & 0.71 & 0.77 \\
\hline 10039 sin. & 0.63 & 0.63 & $10016 \sin$. & 0.66 & 0.72 \\
\hline 10040 sin. & 0.76 & 0.71 & $10017 \sin$. & 0.70 & 0.82 \\
\hline 10041 sin. & 0.65 & - & 5398 sin. & 0.60 & 0.73 \\
\hline 10042 sin. & 0.66 & 0.69 & 10018 dext. & 0.69 & 0.79 \\
\hline 10043 sin. & 0.66 & 0.72 & 10019 dext. & 0.71 & 0.83 \\
\hline 10044 sin. & 0.72 & 0.73 & $10020 \sin$. & 0.63 & 0.74 \\
\hline 10045 dext. & 0.72 & 0.75 & $10021 \sin$. & 0.71 & 0.77 \\
\hline 10046 dext. & 0.71 & 0.73 & $10022 \sin$. & 0.63 & 0.70 \\
\hline 10047 dext. & 0.67 & 0.71 & $10023 \sin$. & 0.64 & 0.73 \\
\hline 10048 dext. & 0.78 & 0.78 & $10024 \sin$. & 0.67 & 0.76 \\
\hline 10049 dext. & 0.75 & 0.75 & $10025 \sin$. & 0.66 & 0.75 \\
\hline 10050 dext. & 0.76 & 0.75 & $10026 \sin$. & 0.69 & 0.80 \\
\hline 10051 dext. & 0.78 & 0.78 & $10027 \sin$. & 0.65 & 0.71 \\
\hline 10052 dext. & 0.74 & 0.73 & 10028 sin. & 0.66 & 0.76 \\
\hline 10053 dext. & 0.74 & 0.74 & 5522 dext. & 0.66 & 0.77 \\
\hline 10054 dext. & 0.68 & 0.67 & $10029 \sin$. & 0.67 & 0.73 \\
\hline 10055 dext. & 0.77 & 0.77 & 5399 sin. & 0.71 & 0.80 \\
\hline 10056 dext. & 0.71 & 0.75 & 10030 dext. & 0.66 & 0.76 \\
\hline 5386 dext. & 0.71 & 0.75 & 10031 dext. & 0.66 & 0.78 \\
\hline 5401 dext. & 0.85 & 0.78 & 10032 dext. & 0.65 & 0.79 \\
\hline Mean & 0.725 & 0.7324 & 10033 dext. & 0.65 & 0.74 \\
\hline \multirow[t]{2}{*}{$\mathrm{SD}$} & 0.0523 & 0.0390 & 10034 dext. & 0.71 & 0.84 \\
\hline & & & 10035 dext. & 0.67 & 0.77 \\
\hline M3 & & & 10036 dext. & 0.68 & 0.76 \\
\hline 413 sin. & 0.54 & 0.68 & 484 sin. c. $6 j$ & 0.75 & 0.82 \\
\hline $414 \sin$. & 0.52 & 0.69 & 485 dext. fig. $6 \mathrm{k}$ & 0.67 & 0.75 \\
\hline 415 dext. & 0.59 & 0.66 & 10303 dext. & 0.65 & 0.75 \\
\hline 416 dext. & 0.50 & 0.60 & Mean & 0.6714 & 0.7652 \\
\hline Mean & 0.5375 & 0.6575 & SD & 0.0313 & 0.0354 \\
\hline SD & 0.0386 & 0.0403 & & & \\
\hline
\end{tabular}

The full inventory number of each specimen is BSPG 1959 II plus the given number. Cited figures are in Fahlbusch 1975

eomyids from MN5 and MN6. Many scholars followed this opinion, including Schötz (1979), Bolliger (1992), Ziegler (1995) and Mörs et al. (2000).

From some Swiss Molasse localities Engesser (1990) expressed an opposite position and distinguished $K$. thaleri in MN5 from $K$. carpathicus in MN6. He observed that the M3 of $K$. thaleri, which was unknown from Vieux Collonges, shows a long mesoloph whereas this crest is reduced or even absent in K. carpathicus; the mesolophid on $\mathrm{m} 3$ is also more reduced in the latter species.

Later, Heissig (1997) showed in a biostratigraphical framework of the Bavarian Upper Freshwater Molasse that 
Table 3 Measurements (mm) of M1-2 of Keramidomys thaleri from Sandelzhausen, including mean and standard deviation

\begin{tabular}{|c|c|c|c|c|c|}
\hline Inventory no. & Length & Width & Inventory no. & Length & Width \\
\hline M1-2 (M1) & & & M1-2 (M2) & & \\
\hline 10333 sin. & 0.76 & 0.86 & 10348 sin. & 0.65 & 0.85 \\
\hline 10334 sin. & 0.73 & 0.86 & $10349 \sin$. & 0.73 & - \\
\hline 10335 sin. & 0.72 & 0.79 & 10350 sin. & 0.66 & 0.77 \\
\hline 10337 sin. & 0.78 & 0.90 & 10351 sin. & 0.72 & 0.81 \\
\hline 10338 sin. & 0.80 & 0.85 & $10352 \sin$. & 0.69 & 0.85 \\
\hline 10339 sin. & 0.78 & 0.84 & 10353 sin. & 0.65 & 0.80 \\
\hline 10340 sin. & 0.72 & 0.76 & 10354 sin. & 0.64 & 0.76 \\
\hline $10341 \sin$. & 0.74 & 0.76 & $10355 \sin$. & 0.66 & 0.75 \\
\hline $10342 \sin$. & 0.77 & 0.82 & $5404 \sin$. & 0.62 & 0.74 \\
\hline $10343 \sin$. & 0.76 & 0.87 & $5405 \sin$. & 0.65 & 0.85 \\
\hline $10344 \sin$. & 0.74 & 0.87 & $5406 \sin$. & 0.69 & 0.85 \\
\hline $10345 \sin$. & 0.73 & 0.78 & $10356 \sin$. & 0.65 & 0.79 \\
\hline $10346 \sin$. & 0.75 & 0.84 & $10357 \sin$. & 0.67 & 0.80 \\
\hline $5523 \sin$. & 0.77 & 0.88 & $10358 \sin$. & - & 0.81 \\
\hline $10347 \sin$. & 0.80 & 0.84 & $10359 \sin$. & 0.62 & - \\
\hline 10360 dext. & 0.71 & 0.83 & $5524 \sin$. & 0.80 & - \\
\hline 10361 dext. & 0.74 & 0.78 & $10336 \sin$. & 0.63 & 0.71 \\
\hline 10362 dext. & 0.76 & 0.89 & 10377 dext. & 0.65 & 0.80 \\
\hline 10363 dext. & 0.72 & 0.86 & 10378 dext. & 0.68 & 0.80 \\
\hline 10364 dext. & 0.76 & 0.84 & 10379 dext. & 0.67 & 0.80 \\
\hline 5383 dext. & 0.77 & 0.81 & 10380 dext. & 0.67 & 0.82 \\
\hline 5400 dext. & 0.70 & 0.78 & 10381 dext. & 0.72 & 0.87 \\
\hline 5402 dext. & 0.78 & 0.85 & 10382 dext. & 0.69 & 0.85 \\
\hline 5403 dext. & 0.76 & 0.87 & 10383 dext. & 0.69 & 0.86 \\
\hline 10365 dext. & 0.80 & 0.90 & 10385 dext. & 0.68 & 0.89 \\
\hline 10366 dext. & 0.76 & 0.85 & 10386 dext. & 0.69 & 0.86 \\
\hline 10367 dext. & 0.76 & 0.85 & 10387 dext. & 0.65 & 0.80 \\
\hline 10368 dext. & 0.80 & 0.88 & 5407 dext. & 0.66 & 0.80 \\
\hline 10369 dext. & 0.76 & 0.84 & 10387 dext. & 0.65 & 0.80 \\
\hline 10370 dext. & 0.77 & 0.89 & 10388 dext. & 0.64 & 0.80 \\
\hline 10371 dext. & 0.76 & 0.85 & 10389 dext. & 0.66 & 0.81 \\
\hline 10372 dext. & 0.77 & 0.89 & 10390 dext. & 0.62 & 0.77 \\
\hline 10373 dext. & 0.74 & 0.84 & 10391 dext. & 0.59 & 0.77 \\
\hline 10374 dext. & 0.74 & 0.85 & 10392 dext. & 0.60 & 0.83 \\
\hline 10375 dext. & 0.79 & 0.86 & 5525 dext. & 0.62 & - \\
\hline 10376 dext. & 0.77 & 0.87 & 486 sin. fig. $6 n$ & 0.60 & 0.78 \\
\hline 489 dext. fig. $6 \mathrm{~m}$ & 0.74 & 0.85 & 487 sin. fig. 60 & 0.69 & 0.80 \\
\hline 490 dext. fig. 61 & 0.79 & 0.84 & 488 sin. fig. $6 p$ & 0.67 & 0.80 \\
\hline 10384 dext. & 0.75 & 0.86 & Mean & 0.6627 & 0.8074 \\
\hline Mean & 0.7577 & 0.8449 & SD & 0.0405 & 0.0395 \\
\hline SD & 0.0257 & 0.0366 & & & \\
\hline
\end{tabular}

The full inventory number of each specimen is BSPG 1959 II plus the given number. Cited figures are in Fahlbusch 1975

the Sandelzhausen fauna is older than was expected. In his opinion this fauna belongs to the lithostratigraphic unit OSM-C within MN5 and not to MN6. So, the
Table 4 Measurements (mm) of m1-2 of Keramidomys thaleri from Sandelzhausen, including mean and standard deviation

\begin{tabular}{|c|c|c|c|c|c|}
\hline Inventory no. & Length & Width & Inventory no. & Length & Width \\
\hline $\mathrm{m} 1-2$ & & & $\mathrm{~m} 1-2$ & & \\
\hline $5395 \sin$. & 0.75 & 0.80 & 482 dext. & 0.73 & 0.76 \\
\hline $10282 \sin$. & 0.76 & 0.77 & 483 dext. fig. $6 f$ & 0.78 & 0.76 \\
\hline $10283 \sin$. & 0.76 & 0.76 & 5384 dext. & 0.82 & 0.79 \\
\hline $10284 \sin$. & 0.76 & 0.73 & 10309 dext. & 0.79 & 0.78 \\
\hline $10285 \sin$. & 0.83 & 0.82 & 10310 dext. & 0.78 & 0.81 \\
\hline $10286 \sin$. & 0.79 & 0.78 & 10311 dext. & 0.80 & 0.77 \\
\hline $10287 \sin$. & 0.83 & 0.80 & 10312 dext. & 0.71 & 0.69 \\
\hline $10288 \sin$. & 0.73 & 0.74 & 5385 dext. & 0.72 & 0.75 \\
\hline $10289 \sin$. & 0.79 & 0.80 & 10313 dext. & 0.76 & 0.72 \\
\hline 10290 sin. & 0.76 & 0.73 & 10314 dext. & 0.76 & 0.77 \\
\hline 10291 sin. & 0.66 & 0.78 & 10315 dext. & 0.76 & 0.78 \\
\hline $10292 \sin$. & 0.69 & 0.74 & 10316 dext. & 0.81 & 0.82 \\
\hline 10293 sin. & 0.75 & 0.73 & 10317 dext. & 0.74 & 0.77 \\
\hline 10294 sin. & 0.76 & 0.77 & 10318 dext. & 0.76 & 0.71 \\
\hline 10295 sin. & 0.72 & 0.76 & 10319 dext. & 0.77 & 0.76 \\
\hline $10296 \sin$. & 0.72 & 0.76 & 10320 dext. & 0.71 & 0.76 \\
\hline 10297 sin. & 0.70 & 0.72 & 10321 dext. & 0.77 & 0.80 \\
\hline 10298 sin. & 0.79 & 0.76 & 10322 dext. & 0.76 & 0.74 \\
\hline 10299 sin. & 0.78 & 0.75 & 10323 dext. & 0.79 & 0.71 \\
\hline 10300 sin. & 0.80 & 0.81 & 10324 dext. & 0.82 & 0.81 \\
\hline 10301 sin. & 0.69 & 0.77 & 10325 dext. & 0.81 & 0.80 \\
\hline 10302 sin. & 0.66 & 0.68 & 10326 dext. & 0.71 & 0.71 \\
\hline 10304 sin. & 0.72 & 0.77 & 10327 dext. & 0.77 & 0.73 \\
\hline 10305 sin. & 0.75 & 0.79 & 5393 dext. & 0.76 & 0.74 \\
\hline 10306 sin. & 0.78 & 0.76 & 5438 dext. & 0.79 & 0.74 \\
\hline 10307 sin. & 0.71 & 0.78 & 10328 dext. & 0.67 & 0.70 \\
\hline 5526 sin. & 0.72 & 0.75 & 10329 dext. & 0.76 & 0.80 \\
\hline 72 dext. fig. $6 \mathrm{~h}$ & 0.76 & 0.78 & 10330 dext. & 0.80 & 0.85 \\
\hline 473 sin. & 0.75 & 0.78 & 10331 dext. & 0.74 & 0.70 \\
\hline 474 sin. & 0.81 & 0.84 & 10332 dext. & 0.79 & 0.80 \\
\hline 475 sin. & 0.80 & 0.78 & 5394 dext. & - & 0.78 \\
\hline 476 sin. & 0.78 & 0.79 & 5518 dext. & 0.62 & 0.67 \\
\hline 477 sin. fig. $6 e$ & 0.77 & 0.82 & 417 dext. & 0.76 & 0.77 \\
\hline 478 dext. fig. $6 g$ & 0.77 & 0.75 & 5521 dext. & 0.68 & 0.66 \\
\hline 479 dext. & 0.80 & 0.80 & Mean & 0.7570 & 0.7638 \\
\hline 480 dext. & 0.85 & 0.81 & $\mathrm{SD}$ & 0.0447 & 0.0392 \\
\hline 481 dext. fig. $6 j$ & 0.74 & 0.76 & & & \\
\hline
\end{tabular}

The full inventory number of each specimen is BSPG 1959 II plus the given number. Cited figures are in Fahlbusch 1975

Keramidomys found in Sandelzhausen must be chronologically linked to $K$. thaleri from Vieux Collonges. Furthermore many localities studied in Fahlbusch (1975) and mentioned in Fahlbusch \& Bolliger (1996) in spite of the poor material probably contained the same species. Daxner-Höck (1998) worked on an important collection from two localities in Austria: Teiritzberg and 
Table 5 Measurements (mm) of d4, p4, m3 of Keramidomys thaleri from Sandelzhausen, including mean and standard deviation

\begin{tabular}{|c|c|c|c|c|c|}
\hline Inventory no. & Length & Width & Inventory no. & Length & Width \\
\hline \multicolumn{3}{|l|}{$\mathrm{d} 4$} & \multicolumn{3}{|l|}{$\mathrm{m} 3$} \\
\hline $631 \mathrm{sin}$. & 0.81 & 0.60 & 10393 sin. & 0.60 & 0.62 \\
\hline $632 \sin$. & 0.78 & 0.60 & $10394 \sin$. & 0.69 & 0.63 \\
\hline $633 \mathrm{sin}$. & 0.82 & 0.60 & $10395 \mathrm{sin}$. & 0.71 & 0.72 \\
\hline $634 \sin$. & 0.77 & 0.60 & $5396 \mathrm{sin}$. & 0.64 & 0.63 \\
\hline $635 \sin$. & 0.83 & 0.59 & 10396 sin. & 0.68 & 0.60 \\
\hline $636 \mathrm{sin}$. & 0.78 & 0.58 & $1039 \mathrm{sin}$. & 0.71 & 0.66 \\
\hline $637 \sin$. & 0.81 & 0.58 & 10398 sin. & 0.65 & 0.67 \\
\hline 638 dext. & 0.77 & 0.52 & $10399 \sin$. & 0.60 & 0.64 \\
\hline Mean & 0.7962 & 0.5837 & $10400 \sin$. & 0.64 & 0.63 \\
\hline \multirow[t]{2}{*}{ SD } & 0.02 & 0.03 & $5519 \sin$. & 0.67 & 0.65 \\
\hline & & & 10401 dext. & 0.64 & 0.64 \\
\hline $\mathrm{p} 4$ & & & 10402 dext. & 0.71 & 0.64 \\
\hline $533 \sin$. & 0.72 & 0.66 & 10403 dext. & 0.65 & 0.74 \\
\hline $534 \sin$. & 0.73 & 0.66 & 10404 dext. & 0.67 & 0.62 \\
\hline $535 \sin$. & 0.76 & 0.69 & 10405 dext. & 0.72 & 0.63 \\
\hline $536 \sin$. & 0.71 & 0.64 & 10406 dext. & 0.68 & 0.68 \\
\hline $537 \sin$. & 0.74 & 0.67 & 10407 dext. & 0.68 & 0.66 \\
\hline $538 \sin$. & 0.71 & 0.65 & 10408 dext. & 0.65 & 0.66 \\
\hline $539 \sin$. & 0.73 & 0.63 & 10409 dext. & 0.60 & 0.64 \\
\hline $540 \sin$. & 0.74 & 0.64 & 5397 dext. & 0.69 & 0.70 \\
\hline $541 \sin$. & 0.76 & 0.72 & 5520 dext. & 0.69 & 0.70 \\
\hline 542 dext. & 0.74 & 0.66 & 10410 dext. & 0.62 & 0.64 \\
\hline 543 dext. & 0.67 & 0.65 & 10411 dext. & 0.68 & 0.71 \\
\hline 544 dext. & 0.72 & 0.65 & 10412 dext. & 0.61 & 0.63 \\
\hline 545 dext. & 0.71 & 0.7 & Mean & 0.6617 & 0.6558 \\
\hline 546 dext. & 0.71 & 0.66 & SD & 0.0365 & 0.0356 \\
\hline 547 dext. & 0.67 & 0.6 & & & \\
\hline 548 dext. & 0.77 & 0.67 & & & \\
\hline 549 dext. & 0.67 & 0.63 & & & \\
\hline 550 dext. & 0.67 & 0.67 & & & \\
\hline 551 dext. & 0.75 & 0.68 & & & \\
\hline 5388 dext. & 0.77 & 0.72 & & & \\
\hline 5392 dext. & 0.76 & 0.65 & & & \\
\hline $467 \sin$. & 0.72 & 0.69 & & & \\
\hline 468 dext. & 0.78 & 0.66 & & & \\
\hline 469 dext. (fig. 6b) & 0.75 & 0.67 & & & \\
\hline 470 dext. (fig. 6a) & 0.77 & 0.74 & & & \\
\hline 471 dext. (fig. 6c) & 0.76 & 0.63 & & & \\
\hline 472 dext. (fig. 6d) & 0.73 & 0.69 & & & \\
\hline Mean & 0.7304 & 0.6659 & & & \\
\hline SD & 0.0330 & 0.0312 & & & \\
\hline
\end{tabular}

The full inventory number of each specimen is BSPG 1959 II plus the given number. Cited figures are in Fahlbusch 1975

Obergänserndorf, both belonging to MN5. The material was compared in detail with the MN6 collection from Neudorf Spalte (Slovak Republic). In conclusion, she recognised the validity of two different species and defined explicit new differential characters. For $K$. thaleri, the mesoloph length is greater and the mesolophid is more developed in the $\mathrm{d} 4$ and on the $\mathrm{p} 4$. Moreover in the M2, the longitudinal crest is complete in $10 \%$ of the sample, though this crest is always interrupted in K. carpathicus. Therefore it is necessary to have a sufficient sample to provide a positive determination. However, Obergänserndorf is an unusual site where the genus Keramidomys represents 32\% of the rodent fauna; in all the other known Early/Middle Miocene localities this proportion is less than $1 \%$.

Finally, Fahlbusch (2003) published a revised list of the Sandelzhausen fauna with $K$. thaleri being the only eomyid.

\section{Description of $K$. thaleri from Sandelzhausen}

The Sandelzhausen site yielded a great number of teeth of this species but among the huge number of rodent teeth it is not especially well represented. Measurements of Sandelzhausen teeth are given in Tables 2, 3, 4, and 5, and for comparisons measurements of Vieux Collonges (France) teeth are listed in Table 6.

\section{Upper dentition}

The tooth size of each category is nearly the same. The width is only slightly larger than the length; all teeth have three roots. Determining the intermediate teeth (M1 and M2) is not easy. Numerous maxillae were found only in Neudorf Spalte. Fejfar (1974), Engesser (1990) and Daxner-Höck (1998) mentioned that M1s are larger than M2s with a rounded posterior edge, whereas M2 are smaller with a straight posterior margin. The length/width dispersion diagrams largely overlap; in stratigraphically younger sites the size difference becomes more important (Fig. 1).

\section{D4}

Twenty-two teeth were collected, of which two are worn or damaged.

These teeth show a buccal border that is longer than the lingual one, which can be reduced imparting a trapezoidal outline to the tooth. The anteroloph is well developed in the buccal part where it joins the protoloph in 13 teeth out of 22. In two teeth this crest is short and ends before it connects with the protoloph. In five teeth this crest is completely fused to the protoloph. In 20 teeth the longitudinal crest is completely broken behind the protocone and in only two teeth (nos. 10048 and 10055) does it show 
Table 6 Measurements (mm) of teeth of Keramidomys thaleri from Vieux Collonges (France) including mean and standard deviation

\begin{tabular}{|c|c|c|c|c|c|}
\hline Inventory no. & Length & Width & Inventory no. & Length & Width \\
\hline D4 & & & D4 & & \\
\hline No Nr. sin. & 0.16 & 0.71 & $65334 \sin$. & 0.78 & 0.58 \\
\hline No Nr. sin. & 0.77 & 0.78 & $65335 \sin$. & 0.67 & - \\
\hline Mean & 0.465 & 0.745 & Mean & 0.725 & \\
\hline $\mathrm{SD}$ & 0.4313 & 0.0495 & $\mathrm{SD}$ & 0.0778 & \\
\hline $\mathrm{P} 4$ & & & $\mathrm{p} 4$ & & \\
\hline 65325 dext. (fig. 18) & 0.70 & 0.80 & $65336 \sin$. & 0.72 & 0.68 \\
\hline No Nr. sin. (fig. 8) & 0.70 & 0.82 & 65337 dext. & 0.76 & 0.67 \\
\hline No Nr. & 0.69 & 0.79 & 65338 dext. (fig. 13) & 0.75 & 0.63 \\
\hline No Nr. & 0.71 & 0.79 & 65339 dext. & 0.70 & 0.63 \\
\hline Mean & 0.70 & 0.8 & No Nr. sin. & 0.79 & 0.70 \\
\hline \multirow[t]{2}{*}{$\mathrm{SD}$} & 0.01 & 0.01 & No Nr. & 0.72 & 0.74 \\
\hline & & & No Nr. sin. & 0.77 & 0.75 \\
\hline M1 & & & Mean & 0.7444 & 0.6857 \\
\hline 65326 dext. (fig. 19) & 0.80 & 0.91 & $\mathrm{SD}$ & 0.0318 & 0.0479 \\
\hline 65327 dext. & 0.75 & 0.87 & & & \\
\hline 6328 dext. (fig. 20) & 0.76 & 0.80 & $\mathrm{~m} 1$ & & \\
\hline 65329 dext. & 0.76 & 0.87 & No Nr. dext. & 0.73 & 0.75 \\
\hline $65332 \sin$. & 0.77 & 0.84 & No Nr. dext. & 0.76 & 0.76 \\
\hline No Nr. sin. & 0.76 & 0.79 & No Nr. dext. & 0.76 & 0.78 \\
\hline No Nr. dext. & 0.76 & 0.86 & No Nr. (fig. 8d) & 0.75 & 0.74 \\
\hline No Nr. dext. & 0.80 & 0.91 & Mean & 0.75 & 0.7575 \\
\hline Mean & 0.7703 & 0.8564 & $\mathrm{SD}$ & 0.0171 & 0.0171 \\
\hline \multirow[t]{2}{*}{ SD } & 0.0197 & 0.0445 & & & \\
\hline & & & $\mathrm{m} 2$ & & \\
\hline M2 & & & 65340 sin. (fig. 15) & 0.69 & 0.78 \\
\hline 65330 dext. & 0.73 & 0.83 & $65341 \sin$. & 0.72 & 0.76 \\
\hline 65331 sin. & 0.71 & 0.83 & No Nr. sin. & 0.74 & 0.77 \\
\hline 6333 sin. (fig. 21) & 0.61 & 0.78 & No Nr. dext. & 0.74 & 0.76 \\
\hline No Nr. sin. & 0.74 & 0.83 & Mean & 0.7225 & 0.7675 \\
\hline No Nr. sin. & 0.80 & 0.92 & $\mathrm{SD}$ & 0.0236 & 0.0096 \\
\hline No Nr. dext. & 0.75 & 0.85 & & & \\
\hline No Nr. dext. & 0.75 & 0.92 & $\mathrm{~m} 3$ & & \\
\hline Mean & 0.7271 & 0.8514 & 65343 sin. (fig. 16) & 0.62 & 0.63 \\
\hline \multirow[t]{4}{*}{ SD } & 0.0585 & 0.0515 & 65342 dext. (fig. 17) & 0.61 & 0.58 \\
\hline & & & No Nr. sin & 0.66 & 0.64 \\
\hline & & & Mean & 0.63 & 0.6167 \\
\hline & & & SD & 0.0265 & 0.0321 \\
\hline
\end{tabular}

All specimens are from the collection of the University Claude Bernard-Lyon 1 (Faculté des Sciences Lyon, FSL). For the specimens which are inventoried the complete inventory number is: FSL xxxxx. Cited figures are in Hugueney \& Mein 1968

a connection between the longitudinal crest and the protoloph; so generally a deep valley crosses the tooth from the sinus to the buccal syncline II. In 15 out of 22 teeth $(68 \%)$ the mesoloph is long, in $6(27 \%)$ it is medium, and in $1(5 \%)$ it is short. In one tooth (no. 5401) the mesoloph extends forwards and ends buccally at the paracone.
P4

In the genus Keramidomys the $\mathrm{P} 4$ has no anteroloph whereas in the oldest European species $K$. thaleri a small anteroloph followed in a shallow syncline I can be present in unworn teeth. In the type locality of Vieux Collonges 

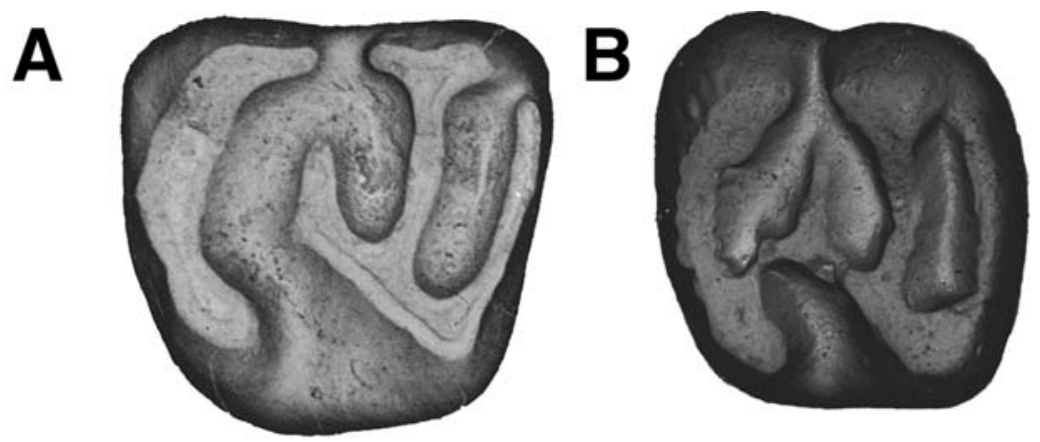

$0,2 \mathrm{~mm}$
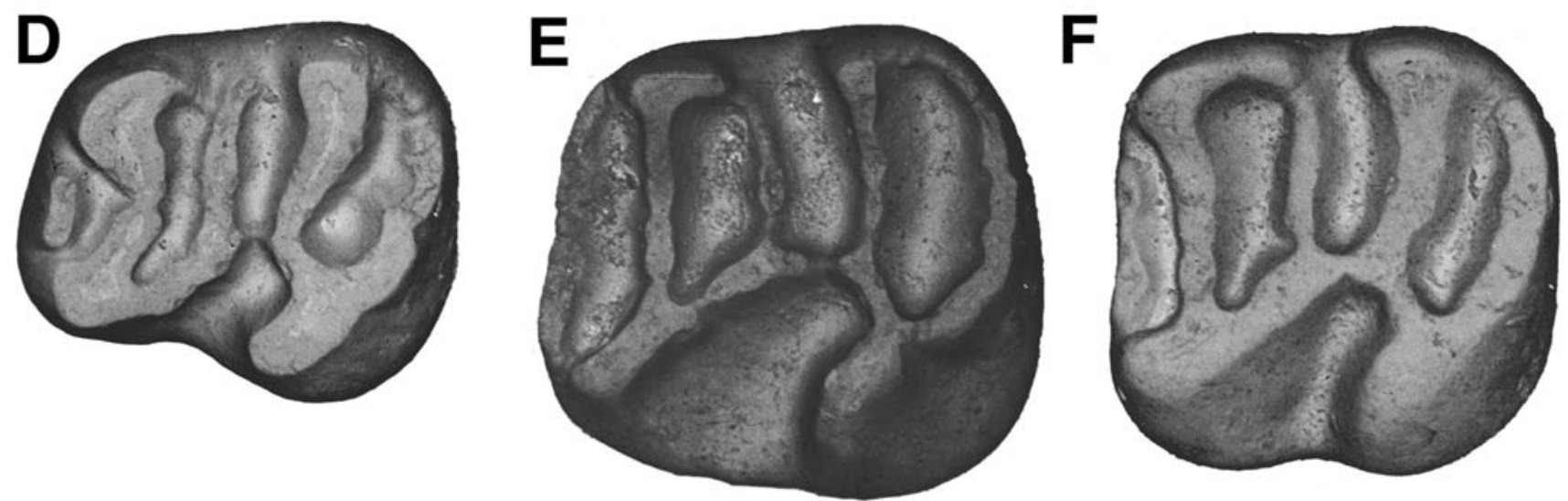

Fig. 1 Teeth of Keramidomys thaleri from Sandelzhausen (MN5), all in occlusal view: a D4 sin. (BSPG 1959 II 5386 ), b P4 sin. (BSPG 1959 II 5387), c M1 dext. (BSPG 1959 II 5383), d p4 dext. (BSPG 1959 II 5388), e m1 dext. (BSPG 1959 II 5384) and f m2 dext. (BSPG 1959 II 5385 )

one P4 out of four shows this typical structure. From Sandelzhausen 4 teeth out of 29 [no. 485 (illustrated in Fahlbusch 1975: fig. 8k), nos. 10018, 10026, 10303] display the same structure. This character is not mentioned in Daxner-Höck (1998) but the figured P4 (Daxner-Höck 1998: fig. 2) has a small anteroloph in its buccal part. This character does not occur in Neudorf Spalte and Sansan. In the Sandelzhausen teeth, the longitudinal crest is complete in 16 teeth out of 28 specimens; in three teeth this crest becomes thinner and lower backwards and ends at the base of the anteroloph; in ten teeth the same crest is interrupted and a deep valley runs from the sinus to the buccal syncline II. One tooth (no. 10303) with a broken longitudinal crest exhibits a second one in the buccal part between the protoloph and metaloph. In Vieux Collonges (France), two teeth out of four have a complete longitudinal crest: one [see Fahlbusch (1975): fig. 8e] ends at the base of the protoloph and one has a broken longitudinal crest. In Sandelzhausen the mesoloph is of medium size in 20 teeth, long in 4 teeth, and short in 5 teeth. In Obergänserndorf, the majority of P4s have the mesoloph of medium length but in Neudorf Spalte this crest is short. I noted a tooth (no. 10034) with a peculiar morphology: its longitudinal crest is complete and well connected to the protoloph but the protocone is separated from the protoloph and there is a medial valley following the sinus.

\section{M1-M2}

Seventy-six M1-2 are represented and tentatively separated into $36 \mathrm{M} 1$ and $40 \mathrm{M} 2$.

The anteroloph is well developed lingually connected to the protoloph. In four specimens the protoloph ends at the base of the protocone. In 20 teeth the anteroloph is buccally connected to the paracone. The first buccal syncline is always clearly visible. The longitudinal crest is broken in 62 teeth. In four teeth there is a connection of this crest with the base of the protoloph (Fahlbusch 1975: fig. 6h). In nine other teeth this longitudinal crest is high and complete (Fahlbusch 1975: fig. 6o). These 13 teeth are all supposed to be M2 in spite of the large size of three of them (nos. 10343-10345). The mesoloph is long in 68 teeth, medium sized in 7, and short in 1. A thin ectoloph can be observed in 13 teeth (Fahlbusch 1975: fig. 6). When the ectoloph is incomplete we can often see a buccal connection between the mesoloph and paracone and also between the metacone and posteroloph. In a small M2 (no. 10336) the longitudinal crest is almost absent and the medium part 
of the mesoloph is isolated but a new and weak lingual connection appears between protocone and hypocone (endoloph); this peculiar morphology can be seen in $25 \%$ of the M2s from Obergänserndorf (Daxner-Höck 1998: 374) but in only one specimen from Sandelzhausen. By comparison, in Vieux Collonges 15 M1-2s have been collected; only one M2 has a complete longitudinal crest, the mesoloph is long in 13 teeth and medium sized in 2 . The welldeveloped first buccal syncline the length of the mesoloph and the presence of a complete longitudinal crest in $10 \%$ of M2 indicates that these specimens should be attributed to $K$. thaleri.

\section{M3}

Only four M3 have been found at Sandelzhausen. These teeth are smaller and more triangular than the M1-2 with a narrow lingual border. These teeth show five lophs; the anteroloph is followed in a long syncline I. In tooth no. 415 the protoloph ends before the protocone so the buccal synclines I and II are communicating.

\section{Lower dentition}

The $\mathrm{d} 4$ and the $\mathrm{p} 4$ have two roots whereas the $\mathrm{m} 1$ and $\mathrm{m} 2$ have four roots: two anterior and two posterior, while the $\mathrm{m} 3$ shows three roots: two anterior and one posterior; this special radiculation seems to be constant among all the species of Keramidomys.

Eight specimens have been found in Sandelzhausen.

It is an elongated tooth narrow in the front with four lophids. The anteroconid is short and isolated in four teeth out of eight. It can form an arcuate crest connected both to the protoconid and the metaconid (one case out of eight) or be connected only to the metaconid (one case out of eight) or the protoconid (one case out of eight). In one tooth (no. 634) the anteroconid is split into two parts, the first connected to the protoconid and the other to the metaconid. The longitudinal crest is complete from protolophid to hypolophid (one case out of eight) but thinner behind the protoconid (three cases out of eight) or disappears between the protoconid and mesoconid. The long mesolophid reaches the lingual edge; it is connected with the metaconid (seven cases out of eight). The sinusid is oriented backwards.

Two d4s have been collected at Vieux Collonges; one has an interrupted longitudinal crest; the other is an aberrant tooth without anteroconid. Both have a long mesolophid. p4

Twenty-seven specimens have been collected from Sandelzhausen.

The permanent premolar is stouter than the deciduous tooth. The anterolophid is developed as a fifth lophid in 25 teeth; in the two other teeth it is reduced to a single cuspid. Usually the anterolophid is connected with the protoconid ( 24 teeth); it can also connect to the metaconid (five teeth). The mesolophid is long in only one tooth (no. 534); usually it does not reach the lingual edge; it is often lingually connected with the metaconid (in 16 teeth) and is seldom connected with the enteroconid, forming a small entolophid (in two teeth); its buccal end can be swollen into a small mesoconid (three teeth). The longitudinal crest is complete in 25 teeth out of 27; in one tooth (no. 542) this crest is cut between mesolophid and hypolophid, and in the tooth no. 544 there is no longitudinal crest.

In comparison, seven $\mathrm{p} 4 \mathrm{~s}$ are known from Vieux Collonges, all of which show five lophids. The anterolophid is connected only with the protoconid. The long mesolophid is often thinner than the other lophids. In one tooth this crest is interrupted in the middle. At the buccal end of the mesolophid two teeth exhibit one mesoconid (Hugueney \& Mein 1968: fig. 13). The longitudinal crest is complete. In one tooth (FSL 65349) the hypolophid does not reach the longitudinal crest buccally.

In $K$. carpathicus the anterolophids and the mesolophids are notably more reduced.

$\mathrm{m} 1-\mathrm{m} 2$

The Sandelzhausen locality yielded 71 isolated $\mathrm{m} 1$ or $\mathrm{m} 2$ teeth, but it is nearly impossible to separate all the specimens into $\mathrm{m} 1$ or $\mathrm{m} 2$. It is accepted in general that the larger ones belong to the $\mathrm{m} 1 \mathrm{~s}$ and the smaller ones to the $\mathrm{m} 2 \mathrm{~s}$. If the width-to-length ratio is less than 1 , the tooth is probably an $\mathrm{m} 1$; if the same ratio is more than 1.1 , the tooth is probably an m2. Fejfar (1974: fig. 17) showed for K. carpathicus that the anterior roots of $\mathrm{m} 2$ are more spindly than the posterior ones, but this criterion is not observable in $K$. thaleri. An attempt at discrimination by using the interstitial facets of mesial and distal edges was not conclusive. The anterolophid is long in 64 teeth out of 71, medium sized in 5, and broken in the middle in 2. Lingually the mesolophid of ten teeth connects the metaconid (Fahlbusch 1975: fig. 6f-j). In one tooth (no. 479) a small entolophid can be seen. The longitudinal crest is always complete. The Vieux Collonges site yielded eight teeth. The long mesolophid connects lingually to the metaconid in four teeth. 
m3

Twenty-four teeth have been collected, among which two are heavily worn but they surely had five lophids.

The anterolophid is well developed, usually connected with the protoconid, sometimes with the metaconid. Three teeth show a connection of this crest to the protolophid in the middle of the tooth; this morphology has been illustrated in Engesser (1990: fig. 107c).

The protolophid is long. From the metaconid a lingual crest often joins the different lophids, forming an entolophid. The buccal syncline I is not reduced. The mesolophid may be long (in 14 teeth out of 24), medium sized in four teeth, cut into two parts in three teeth. This crest is absent in one tooth (no. 408) so this specimen shows only four lophids whereas the other have five. In two teeth the mesolophid is connected to the hypolophid in a longitudinal connection. Only three $\mathrm{m} 3 \mathrm{~s}$ have been found at Vieux Collonges, of which two are figured in Hugueney \& Mein (1968); the additional one has a long anteroconid lingually connected to the metaconid. The synclinid 1 is well developed; the mesolophid interrupted in the middle ends lingually in a stylid.

\section{Conclusions}

In this paper, the problem of the taxonomic affiliation of the small Eomyid from Sandelzhausen to the species $K$. thaleri is discussed and finally accepted and supported in the light of different arguments. I completely agree with the chronology proposed by Heissig (1997): Sandelzhausen belongs to the Mammalian Neogene unit MN5. Within this unit only one Keramidomys species is known upon the whole Europe: $K$. thaleri. This species is older than $K$. carpathicus, which is probably its MN6 descendant.

The teeth measurements on large samples show differences between these two species (M1-2 wider and shorter, m1-2 clearly wider); these two forms were among the smallest known mammals. Their weight did not exceed $5 \mathrm{~g}$, so the measurement errors in the minuscule teeth become more important and these characters are imprecise in a restricted sample.

Finally, in the case of a sufficiently numerous population, despite a certain variability, the morphology seems to be useful for discriminating between these two forms. In $K$. thaleri, the M3s have five lophs and the $\mathrm{m} 3 \mathrm{~s}$ bear five lophids. In $K$. carpathicus the same teeth have only four. In $K$. thaleri the buccal syncline 1 is larger than in $K$. carpathicus, as are the mesoloph and the mesolophids. Some characters occur only in a few teeth: a complete longitudinal crest can be observed in $10 \%$ of K. thaleri and likewise a small anteroloph remains in some P4s.
In conclusion, the numerous teeth from Sandelzhausen measured, analysed and compared with other sites suggest that they must be determined as $K$. thaleri, the only European eomyid in MN5.

Acknowledgments My warmest thanks are expressed to K. Heissig and G. Rössner (both Munich) who invited me to participate in the Sandelzhausen Symposium 2005 at Mainburg. I am grateful to V. Fahlbusch (Munich) who made the CASTL scan images, to M. Pickford (Paris) and D. Hone (Munich) who improved the English and to B. Engesser (Basel) and G. Höck (Vienna) who kindly reviewed this paper.

\section{References}

Aguilar, J.-P., M. Calvet, J.Y. Crochet, S. Legendre, J. Michaux, and B. Sigé. 1986. Première occurrence d'un Mégachiroptère Ptéropodidé dans le Miocène moyen d'Europe (gisement de Lo Fournas IIPyrénées orientales France). Paleovertebrata 16: 173-184.

Bolliger, T. 1992. Kleinsäuger aus der Miozänmolasse der Ostschweiz. Documenta Naturae 75: 1-296.

Daxner-Höck, G. 1998. Säugetiere (Mammalia) aus dem Karpat des Korneuburger Beckens. 3. Rodentia Carnivora. Beiträge zur Paläontologie 23: 367-407.

de Bruijn, H., L. Van Den Hock Ostende, E. Kristkoiz-Boon, M. Rummel, C. Theocharopoulos, and E. Unay. 2003. The rodents lagomorphs and insectivores from the middle Miocene locality Çandir (Anatolia). Courrier Forschungsinstitut Senckenberg 240: 51-87.

Engesser, B. 1979. Relationships of some insectivores and rodents from the Miocene of North America and Europe. Bulletin of the Carnegie Museum of Natural History 14: 1-68.

Engesser, B. 1990. Die Eomyidae (Rodentia Mammalia) der Molasse der Schweiz und Savoyens. Systematik und Biostratigraphie. Schweizerische Paläontologische Abhandlungen 112: 1-144.

Engesser, B. 1999. Family Eomyidae. In The Miocene land mammals of Europe, ed. K. Heissig, and G.E. Rössner, 319-335. Munich: F. Pfeil.

Fahlbusch, V. 1975. Die Eomyiden (Rodentia Mammalia) der oberen Süßwasser-Molasse Bayerns. Mitteilungen der Bayerischen Staatssammlung für Paläontologie und Historische Geologie 15: 63-90.

Fahlbusch, V. 1979. Eomyidae-Geschichte einer Säugetierfamilie. Paläontologische Zeitschrift 53: 88-97.

Fahlbusch, V. 2003. Die miozäne Fossil-Lagerstätte SandelzhausenDie Ausgrabungen 1994-2001. Zitteliana 43: 109-121.

Fahlbusch, V., and T. Bolliger. 1996. Eomyids and Zapodids (Rodentia Mammalia) in the middle and upper Miocene of Central and Southeastern Europe and the Eastern Mediterranean. In The evolution of Western Eurasian Neogene mammal Faunas, ed. R. Bernor, V. Fahlbusch, and H.-W. Mittmann, 208-212. New York: Columbia University Press.

Fahlbusch, V., and W. Wu. 1981. Puttenhausen: Eine neue Kleinsäuger-Fauna aus der Oberen Süßwasser-Molasse Niederbayerns. Mitteilungen der Bayerischen Staatssammlung für Paläontologie und Historische Geologie München 21: 115-119.

Fejfar, O. 1974. Die Eomyiden und Cricetiden (Rod. Mam.) des Miozäns der Tschechoslowakei. Paleontographica 146: 100180.

Hartenberger, J.L. 1967. Les rongeurs du Vallésien (Miocène supérieur) de Can Llobateres (Sabadell Espagne): Gliridae et Eomyidae. Bulletin de la Société Géologique de France (1966) 7e série (8): 596-604. 
Heissig, K. 1989. Neue Ergebnisse zur Stratigraphie der mittleren Serie der Oberen Süsswassermolasse Bayerns. Geologica Bavarica $239-257$.

Heissig, K. 1997. Mammal faunas intermediate between the reference faunas of MN 4 and MN 6 from the Upper freshwater molasse of Bavaria. In Aguilar, J-P., Legendre, S. and Michaux, J. eds., Actes du Congrès Biochrom'97 Biochronologie mammalienne du Cénozoïque en Europe et domaines reliés. Mémoires et Travaux de l'Institut de Montpellier: 537-546.

Höck, V., G. Daxner-Höck, H.P. Schmid, D. Badamgarav, W. Frank, G. Furtmueller, O. Montag, R. Barsbold, Y. Khand, and J. Sodov. 1999. Oligocene-Miocene sediments, fossils and basalts from the Valley of Lakes (Central Mongolia)-an integrated study. Mitteilungen der Österreichischen Geologischen Gesellschaft Wien 90: 83-125.

Hugueney, M., and P. Mein. 1968. Les Eomyidés (Mammalia Rodentia) Néogènes de la région lyonnaise. Geobios 1: 187-204.

Kälin, D. 1997. The Mammal zonation of the Upper marine molasse of Switzerland reconsidered. A local bio-zonation of MN 2-MN 5. In Aguilar, J-P.; Legendre, S. \& Michaux, J. eds., Actes du Congrès Biochrom'97Biochronologie mammalienne du Cénozoïque en Europe et domaines reliés. Mémoires et Travaux de l'Institut de Montpellier: 515-535.

Kowalski, K. 1967. Rodents from the Miocene of Opole. Acta Zoologica Cracoviensia 12: 1-18.

Kowalski, K., and B. Rzebik-Kowalski. 2002. Paleoecology of the Miocene fossil mammal fauna from Belchatow (Poland). Acta Theriologica 47(suppl.1): 115-126.

Mörs, T., F. van der Hocht, and B. Wutzler. 2000. Die erste Wirbeltierfauna aus der miozänen Braunkohle der Niederheinischen Bucht (Ville-Schichten Tagebau Hambach). Paläontologische Zeitschrift 74(1/2): 145-170.

Moser, M., Rössner, G.E., Göhlich, U.B., Böhme, M., and Fahlbusch, V. 2009. The fossil lagerstätte Sandelzhausen (Miocene; southern Germany): history of investigation, geology, fauna and age. In: Rössner, G.E. \& GöHLICH, U.B.: Fossil lagerstätte Sandelzhausen (Miocene, southern Germany): Contributions to the fauna. Paläontologische Zeitschrift 83 (1): 000-000.

Qiu, Z.-D., and X.-M. Wang. 1999. Small mammal Faunas and their ages in Miocene of Centra Nei Mongol (Inner Mongolia). Vertebrata Palasiatica 37: 134-138.

Sach, V.J. 1999. Litho-,und biostratigraphische Untersuchungen in der Oberen Süßwassermolasse des Landkreises Biberach a. d. Riss (Oberschwaben). Stuttgarter Beiträge zur Naturkunde Ser. B: $1-167$.

Schaub, S., and H. Zapfe. 1953. Die Fauna der miozänen Spaltenfüllung von Neudorf an der March (CSR) Simplicidentata. Sitzungsberichte der Österreichischen Akademie der Wissenschaften, Mathematisch-Naturwissenschafliche Klasse 162: 181215.

Schlosser, M. 1926. Die Säugetierfaune von Peublanc (Dép. Allier). Societé des Sciences Naturelles de Croatie (Kramberger Festband) 38(39): 372-393.

Schötz, M. 1979. Neue Funde von Eomyiden aus dem Jungtertiär Niederbayerns. Aufschluss 30: 465-473.

Shotwell, J.A. 1956. Hemiphillian mammalian assemblage from Northeastern Oregon. Bulletin of the Geological Society of America 67: 717-738.

Stehlin, H.G., and S. Schaub. 1951. Die Trigonodontie der simplicidentaten Nager. Schweizerische Paläontologische Abhandlungen 67: 1-385.

Unay, E., and H. de Bruijn. 1984. On some Neogene rodent assemblages from both sides of the Dardanelles Turkey. Newsletters on Stratigraphy Berlin 13(3): 119-132.

Ziegler, R. 1995 . Die untermiozänen Kleinsäugerfaunen aus den Süßwasserkalken von Engelwies und Schellenfeld bei Sigmaringen (Baden-Württemberg). Stuttgarter Beiträge zur Naturkunde B: 1-53. 